\title{
Turnover of human fat cells and their lipid content
}

\author{
Peter Arner \\ From Animal Obesity - causes, consequences and comparative aspects \\ Uppsala, Sweden. 14-16 June 2015
}

\section{Introduction}

The turnover of fat cells and their lipid content is constantly ongoing in adult life. Fat cell turnover has importance for development of adipose tissue consisting of many small fat cells (hyperplasia) or few but large cells (hypertrophy). The latter is linked to metabolic disorders. Variations in lipids turnover in fat cells is also linked to metabolic disease.

\section{Objectives}

We are interested in measuring the turnover of human fat cells and their lipid content and study their impact on hyperplasia/hypertrophy and its clinical consequences.

\section{Methods}

Lipid and fat cell turnover is measured by incorporation of atmospheric $14 \mathrm{C}$ into triglycerides and DNA of human fat cells. Hyperplasia/hypertrophy is determined by measuring fat mass and fat cell size.

\section{Results}

Decreased turnover of fat cells and their lipid contents is associated with insulin resistance, dyslipidemia and altered metabolic function of fat cells. Low fat cell turnover leads to adipose hypertrophy which is linked to insulin resistance in subcutaneous fat and to dyslipidemia in visceral fat. A transcription factor (EBF-1) regulates hyperplasia/hypertrophy in human adipose tissue and in animal models. Changes in adipose EBF-1 expression is linked to abnormal metabolic function of fat cells and to in vivo insulin resistance.

\section{Conclusions}

Altered turnover of fat cells and their lipid content is important for common clinical disorders.

Correspondence: peter.arner@ki.se

Department of Medicine, Karolinska Institutet, Solna, Sweden
Published: 25 September 2015

doi:10.1186/1751-0147-57-S1-K1

Cite this article as: Arner: Turnover of human fat cells and their lipid content. Acta Veterinaria Scandinavica 2015 57(Suppl 1):K1.

\section{Submit your next manuscript to BioMed Central and take full advantage of: \\ - Convenient online submission \\ - Thorough peer review \\ - No space constraints or color figure charges \\ - Immediate publication on acceptance \\ - Inclusion in PubMed, CAS, Scopus and Google Scholar \\ - Research which is freely available for redistribution

